\title{
Microphytobenthos community production at a near-shore coral reef: seasonal variation and response to ammonium recycled by holothurians
}

\author{
Sven Uthicke $^{1,2, *}$, D. W. Klumpp ${ }^{1}$ \\ ${ }^{1}$ Australian Institute of Marine Science, PMB No 3, Townsville, Queensland 4810, Australia \\ ${ }^{2}$ Institut für Hydrobiologie und Fischereiwissenschaft, Zeiseweg 9, Hamburg, Germany
}

\begin{abstract}
Production of the microphytobenthos community of a near-shore reef in the Great Barrier Reef system was measured on 7 occasions over 13 mo using in situ respirometry with dome chambers. In addition, underwater light levels were recorded, which allowed the construction of in situ production-irradiance $(P-I)$ curves for these sediment communities. During all months the community was distinctly autotrophic, with $24 \mathrm{~h}$ production to respiration (P/R) ratios ranging from 2.9 to 4.4 . We estimated an annual community net-production of $168 \mathrm{~g} \mathrm{C} \mathrm{m}^{-2}$ All parameters expressing the overall magnitude of production (community net and gross production; photosynthetic capacity, $P_{\text {max }}$ ) showed distinctly lower values in winter, indicating a strong seasonality. Between 63 and $75 \%$ of the variation of these parameters was explained by seasonal changes in temperature. Most other P-I curve parameters (light compensation point, $I_{c}$ light saturation point, $I_{k}$ i photosynthetic efficiency, $\alpha$ ) showed less obvious long term temporal patterns and were subject to large variation between single measuring days. A considerable proportion of the variation in $I_{r}, I_{k}$ and $\alpha(46$ to $68 \%)$ could be attributed to daily differences in underwater light conditions, indicating rapid photoadaptation by the microalgal communities to variation in light conditions due to turbidity and/or cloud cover. In in situ enrichment experiments the excretion of holothurians enhanced community net production and $P_{\max }$ by about $12 \%$. The enhancement most likely resulted from a rise of $\mathrm{NH}_{4}{ }^{+}$concentration $\left(0.1 \mu \mathrm{mol} \mathrm{\textrm {i } ^ { - 1 }}\right.$ above the background level). The enhancement due to holothurian excretion products, in conjunction with the low quantum yield efficiency exhibited by the benthic community, indicate that production of benthic microalgae in our study area was limited by the availability of inorganic nitrogen.
\end{abstract}

KEY WORDS: Coral reef ecology - Benthic production - Nutrient cycling Sediments - Holothurians Near-shore reefs

\section{INTRODUCTION}

Coral reefs are regarded as one of the most highly productive marine ecosystems (Sorokin 1990). Carbon fixation and nutrient recycling by benthic microalgal communities plays an important role in maintaining the high productivity in these systems, and microalgal and microheterotrophic production on soft sediments are responsible for 20 to $30 \%$ of the total primary production (Sorokin 1993). Even higher contributions of microphytobenthos production to overall production

•E-mail: s.uthicke@aims.gov.au was estimated for a Western Australian coral reef, where production by benthic microalgal communities accounts for $37 \%$ of the total productivity (Masini 1990). These high figures result from a high primary production of these communities (Sournia 1976, Sorokin 1978) and the large area covered by sediments in the lagoon and on reef flats of coral reefs. On the Great Barner Reef (GBR), Australia, as a whole, $33 \%$ of the areas classified as reef is in fact sandy lagoons with a depth less than $5 \mathrm{~m}$, and an additional $18 \%$ of the reef area is reef flats with sand patches (Furnas et al. 1995). These figures lead to approximately $40 \%$ of the reef area in the GBR being a suitable habitat for benthic microalgal communities. 
The microphytobenthos in sandy reef areas is often dominated by diatoms with much lower numbers of cyanophytes, dinoflagellates and chlorophytes (Uthicke \& Klumpp 1997, Uthicke 1998). The organic carbon fixed by this community may enter the food web via a variety of primary consumers such as sediment feeders or feeding of meiofauna and bacteria. An alternative pathway may be the formation of detritus by dead microalgae and leaching of dissolved organic material (DOM) from disintegrating cells which may then nourish bacteria and ultimately bacterivores or detritivores. This second pathway is supported by a coupling of the production peak of sediment bacteria with that of microlagae (Moriarty et al. 1985). Interestingly, sediment feeders which are abundant on coral reef sediments, such as holothurians, may be a part of both pathways since there is evidence that both living diatoms and detritus are part of their diet (Yingst 1976, Uthicke 1998).

Besides the direct impact on carbon and nutrient cycles through carbon fixation and assimilation of inorganic $N$ and $P$, benthic microalgae, at least in temperate systems, have an important function in oxygenating the upper sediment layers (Baillie 1986). Oxygenation, in combination with the nutrient requirements of the microalgae, reduces the flux of phosphate and $\mathrm{NH}_{4}{ }^{+}$from the pore water to the water column (Sundbäk \& Granéli 1988).

Although several authors have measured benthic production in coral reef sediments (e.g. Sournia 1976. Sorokin 1978, Moriarty et al. 1985, Charpy-Roubaud 1988, Johnstone et al. 1990, Masini 1990), data are sparse, usually obtained in one season, and often extrapolated from hourly measurements to daily or even yearly rates. One major exception is the study by Johnstone et al. (1990), who studied sediment community production in 2 seasons and 2 habitats over several years in the Iagoon of One Tree Island in the southern GBR. Production-irradiance $(P-I)$ curves and $P-I$ curve parameters for tropical microphytobenthos communities under natural conditions are not available. Virtually no data exist on the productivity of sediment communities on near-shore reefs.

In the present study, we investigated seasonal variation in benthic community production on a near-shore reef in the GBR. Besides data on community net and gross production, we present production-irradiance $(P-I)$ curves and $P-I$ parameters, and discuss the influence of light and temperature. This was achieved using an oxygen respirometry technique and 4-chamber data logging respirometers (e.g. Klumpp et al. 1987) equipped with dome chambers. In a previous study, we demonstrated in aquaria experiments that benthic community production is enhanced by relatively small increases in the levels of $\mathrm{NH}_{4}{ }^{+}$excreted by sediment feeding holothurians (Uthicke \& Klumpp 1997). We hypothesised that benthic microalgae in situ may also benefit from holothurian excretion products and thus the interaction between benthic sediment feeders and microalgae forms one component of the 'close-coupling' in coral reef nutrient cycles. Thus, a further objective of the present study is to test the hypothesis that the presence of holothurians is beneficial to in situ benthic microalgal production in coral reefs due to increased availability of nutrients.

\section{MATERIAL AND METHODS}

Study area. All measurements and experiments were performed in Cannon Bay at Great Palm Island $\left(18^{\circ} 41^{\prime} \mathrm{S}, 146^{\circ} 35^{\prime} \mathrm{E}\right)$ in the central section of the GBR. Landwards of the reef flat in Cannon Bay there is a lagoon zone which is characterised by sand patches, intermixed with stands of large brown algae (mainly Sargassum spp:; Schaffelke \& Klumpp 1997a) and patches of coral rubble which are partially covered by turf algae. Benthic fauna is dominated by 2 holothurian species [Holothuria (Halodeima) atra, Stichopus chloronotus], which occur in densities of up to 1 ind. $\mathrm{m}^{-2}$, and a burrowing shrimp (Calianassa sp.). Depending on tide level, water depth in the study area varies between 0.5 and $3.5 \mathrm{~m}$. The area was revisited on 7 field trips each of several days between February 1996 and February 1997. Since only temporal variation was investigated in this study, all measurements were performed in an area of approximately $10 \times 20 \mathrm{~m}$.

Respirometry. We measured benthic microalgal production in a 4 -chamber data logging respirometer described in detail by Klumpp et al. (1987). Four perspex dome chambers were deployed over the benthic community several hours before onset of the measurements to allow recovery after potential disturbances. These chambers enclosed a water volume of $15 \mathrm{l}$, covered a surface sediment area of $0.13 \mathrm{~m}^{2}$ and were equipped with an oxygen probe, inflow, outflow, water sampling ports, and an electric stirrer to enhance mixing of the water (Fig. 1). The dome chamber rims were inserted $3 \mathrm{~cm}$ into the sediment and fixed to the sediment with four $25 \mathrm{~cm}$ steel stakes. Chambers were placed so as to avoid Calianassa spp. mounds. The respirometer was programmed to flush chamber water for $4 \mathrm{~min}$ every $26 \mathrm{~min}$. The flushing phase effectively pumped $15 \mathrm{l}$ of ambient sea water into each dome chamber. Oxygen concentration within the dome chambers, in situ irradiance and water temperature were recorded simultaneously at 1 min intervals. Irradiance (as photosynthetically active irradiance, PAR) was recorded with a Li-Cor $192 \mathrm{SB}$ underwater quantum sensor. All deployments lasted for at least $24 \mathrm{~h}$. 
Trials with a control dome which was closed at the bottom and thus contained only ambient sea water yielded no measurable production or respiration (see also Johnstone et al. 1990). Thus, the control was omitted to achieve higher replication.

Effect of nutrients excreted by holothurians. In December 1996 (2 experimental runs) and February 1997 (3 experimenal runs) we deployed 2 respirometers (total of 8 dome chambers) for $24 \mathrm{~h}$ measurements of benthic community production as described above. In 4 randomly chosen dome chambers per experimenal run, the nutrient levels were enhanced using excretion from holothurians as a natural nutrient source (Uthicke \&

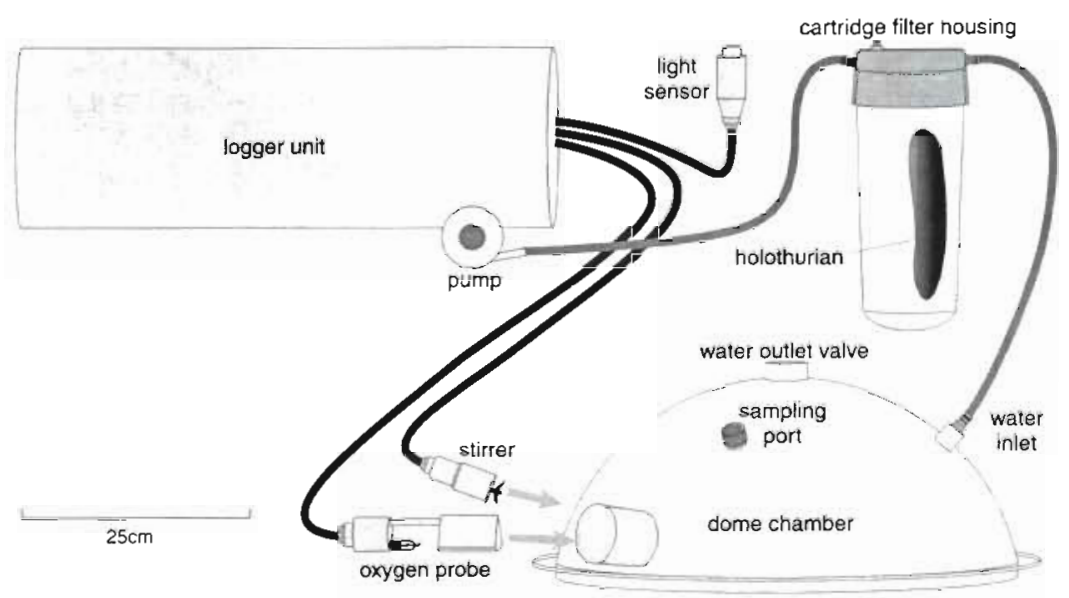

Fig. 1 Schematic diagram of the components of the respirometer with dome chambers as used in nutrient enhancement experiments. In routine respirometry measurements, the filter housing with holothurian was omitted. See Klumpp et al. (1987) for details on respirometer components
Klumpp 1997). This was achieved by enclosing a holothurian of the common species Holothuria atra (weight range: 140 to $220 \mathrm{~g}$ wet-weight) inside a cartridge filter housing connected in-line on the flushing hose (Fig. 1). Individuals of this size class excrete between 3.5 to $4.3 \mu \mathrm{mol} \mathrm{NH}_{4}{ }^{+}$in $30 \mathrm{~min}$ (Uthicke unpubl, data), which was injected into the respirometer chambers during each flushing. Thus, assuming the ammonium is diluted in the volume of 15 I (chamber size), this is equivalent to a maximum $\mathrm{NH}_{4}{ }^{+}$pulse of 0.2 to $0.3 \mu \mathrm{mol}{ }^{-1}$ above the background level every $30 \mathrm{~min}$. However, the real increase in $\mathrm{NH}_{4}{ }^{+}$ will be somewhat below that level, since some of the enriched water will be lost from the chambers during flushing. Since previous experiments indicated no measurable increase of any other inorganic (Uthicke \& Klumpp 1997) or organic (Uthicke unpubl. data) nutrients, only $\mathrm{NH}_{4}{ }^{+}$levels were monitored during the experiment.

Pigment and $\mathrm{NH}_{4}{ }^{+}$analyses. To estimate microalgal biomass in sediments used in the dome chamber experiments, 3 replicate samples of the upper $5 \mathrm{~mm}$ of the sediment were collected under each dome chamber after termination of the experiments. For chlorophyll a analyses, these samples were dried $\left(60^{\circ} \mathrm{C}, 48 \mathrm{~h}\right)$ and $1.5 \mathrm{~g}$ sediment was extracted in $3 \mathrm{ml}$ ethanol $(70 \%)$, following the method of Sartory \& Grobbelaar (1984). Absorbance of the extracts was measured in a spectrophotometer at 750 and $665 \mathrm{~nm}$ before and after acidification and chlorophyll a concentrations were calculated applying the formula of Nusch (1980).

During 4 of the holothurian enclosure experimental runs duplicate water samples for $\mathrm{NH}_{4}{ }^{+}$analyses were taken through the sampling port of all dome chambers on 2 or 3 occasions 5 min after a pumping interval ended. We assumed that water was well mixed after the flushing of the dome chambers and that nutrient levels in the enhanced treatments were then at the maximum. Water samples collected by syringe were immediately filtered through $0.45 \mu \mathrm{m}$ acid washed and precombusted GF/F filters (Whatman) and stored at $-20^{\circ} \mathrm{C}$ until analyses. $\mathrm{NH}_{4}{ }^{+}$was determined after $\mathrm{Ko}-$ roleff (1983), modified to a $10 \mathrm{ml}$ sample volume.

Data analyses. Oxygen production or respiration rates of the benthic community were calculated from linear regressions of oxygen values recorded every minute during each $26 \mathrm{~min}$ incubation period. Irradiance and temperature values were averaged over the same period. Carbon fixation was calculated from the oxygen production data assuming $P Q=R Q=1$ (Sournia 1976); thus, $1 \mathrm{mg}$ oxygen produced or respired is equivalent to $0.375 \mathrm{mg}$ organic carbon. Areal net production (NP) over a $24 \mathrm{~h}$ period in each chamber was calculated by subtracting the total dark respiration (DR) at night from the total production (TP) during day light (NP $=\mathrm{TP}-\mathrm{DR}$ ). Gross production (GP) was obtained by adding $2 \times$ dark respiration data (after correcting for the actual daylength) to the daily production ( $G P=T P+2 \times D R$ ), assuming that dark respiration equals respiration during daytime. Daily production data are thus directly measured over a $24 \mathrm{~h}$ period and not extrapolated from short term observations. We calculated production-irradiance $(P-I)$ parameters $\left(P_{\max }=\right.$ photosynthetic capacity, $I_{k}=$ light saturation point, $I_{c}=$ light compensation point) from hyperbolic tangent functions (Chalker 1981). This model was the best fit for the description of our data on the relation between production and irradiance (compared to a rectangular hyperbola or exponential function); coefficients of dispersion were generally higher than 0.95 . We calculated the photosynthetic efficiency $(\alpha)$ as $\mu \mathrm{mol} \mathrm{O}_{2} \mu \mathrm{E}^{-1}$ 
Using this unit, $\alpha$ is equivalent to the quantum yield efficiency ( $\phi$ in Kirk 1983 and Mills \& Wilkinson 1986) One-factor ANOVAs for each calculated parameter were performed to compare means between the experimental months. On some days, equipment failure or physical disturbance of a dome chamber by swell or burrowing shrimps resulted in the reduction of the replicate number Additionally, we could not measure over the same number of days on each field trip due to weather and time constraints. Thus, the resulting sampling design. was unbalanced and we choose the Tukey HSD test for unequal replicate number as a post-hoc test for comparison of means.

We used multiple regression analysis to investigate the amount of variation in P-I curve parameters, microalgal biomass and production which could be explained by light and temperature changes. Therefore, average values of the former parameters for each measuring day were entered as dependent variables and light and temperature as independent variables. Temperature data are the average water temperature for each day. Underwater light was integrated to total daily light sums and presented in Einsteins $d^{-1}(1 \mathrm{E}=$ 1 mol photons). Initial trials including algal biomass as independent parameter yielded no detectable improvement of the models.

The production parameters and $\mathrm{NH}_{4}{ }^{+}$data from the holothurian enclusore experiment were analysed by a 2-way ANOVA with the factors being 'Treatment' (enhanced vs unenhanced) and experimental. 'Month' (December vs February).

Before subjection to ANOVAs, all data were tested for homogeneity of variances and normality, in the case of nonconformance data were transformed as indicated in the results section.

\section{RESULTS}

\section{Microphytobenthos community production}

All parameters related to in situ measured production showed significant variation between the months of observation (Table 1). Community net and gross production of the microalgal community were positive throughout our study period and showed distinctly reduced values in the 2 winter months (Fig. 2). The summer net $\mathrm{C}$ fixation values varied only slightly between 573 and $790 \mathrm{mg} \mathrm{C} \mathrm{m} \mathrm{C} \mathrm{d}^{-1}$, and were more than twice as high as the winter values. Assuming summer and winter values were each representative of 6 mo of the year, we calculated the average carbon fix-

Table 1. One-way ANOVAs (factor Month) for community net and gross production ( $\mathrm{mg} \mathrm{C} \mathrm{m}^{-2} \mathrm{~d}^{-1}$ ), production to respiration $(\mathrm{P} / \mathrm{R})$ ratios (dimensionless), photosynthetic capacity $\left(P_{\text {max }} ; \mathrm{mg}\right.$ $\left.\mathrm{O}_{2} \mathrm{~min}^{-1} \mathrm{~m}^{-2}\right)$, light saturation point $\left(f_{h}\right)$ and light compensation point $\left(I_{c}\right)\left(\mu \mathrm{E} \mathrm{m}^{-2} \mathrm{~s}^{-1}\right)$, photosynthetic efficiency $\left(\alpha_{i} \mu \mathrm{mol}\right.$ $\mathrm{O}_{2} \mu \mathrm{E}^{-1}$ ) and algal biomass ( $\mathrm{mg} \mathrm{chl} \mathrm{a} \mathrm{m}^{-2}$ ) of microbenthic communities at Great Palm Island, GBR. Degrees of freedom are 6 for the factor and 77 for the error term in each analysis

\begin{tabular}{|lcrc|}
\hline Effect & Transformation & $F$ & $\mathrm{p}$ \\
\hline Net production & $\sqrt{x+1}$ & 23.40 & $<0.001$ \\
Gross production & $\sqrt{x+1}$ & 23.98 & $<0.001$ \\
$\mathrm{P} / \mathrm{R}$ & none & 6.60 & $<0.001$ \\
$P_{\operatorname{mdx}}$ & $\sqrt{X+1}$ & 23.21 & $<0.001$ \\
$I_{c}$ & none & 5.73 & $<0.001$ \\
$I_{\mathrm{k}}$ & $\ln (x+1)$ & 6.52 & $<0.001$ \\
$\alpha$ & $\ln (x+1)$ & 9.80 & $<0.001$ \\
Biomass & $\ln (x+1)$ & 12.48 & $<0.001$ \\
\hline
\end{tabular}

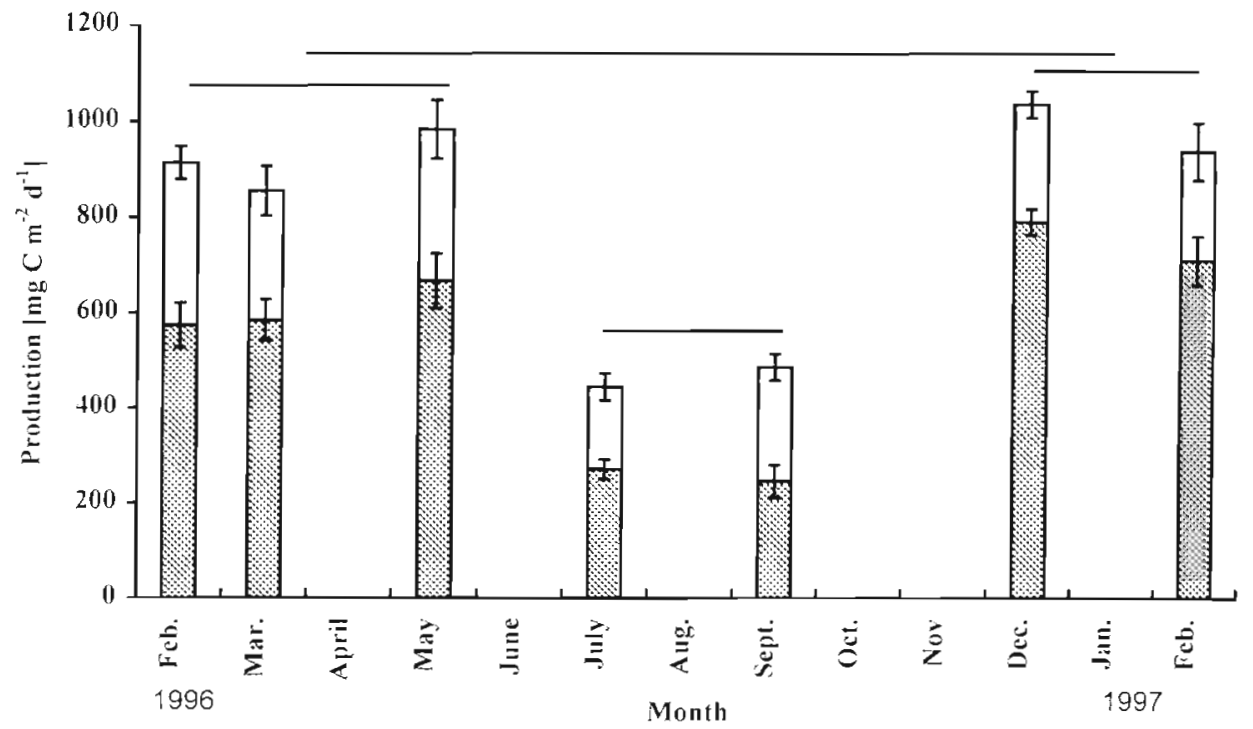

Fig. 2. Average community net production $( \pm \mathrm{SE}$, hatched bar areas) and community gross production $( \pm \mathrm{SE}$, total bar area) on Great Palm Island. GBR. The open bar area represents respiration. Horizontal lines connect means which are not significantly different $(\mathrm{p}>$ 0.5, Tukey HSD test for unequal means) 
Table 2. Monthly average $( \pm \mathrm{SE}$ ) of temperature, light $(\mathrm{n}=2$ to 4 ), light response parameters and chlorophyll a ( $\mathrm{n}$ indicated in table) determined in respirometer experiments with microphytobenthos. Means which share the same index letter are not significantly different (Tukey HSD test for unequal $n$ )

\begin{tabular}{|c|c|c|c|c|c|c|c|c|c|c|}
\hline Month & $\begin{array}{c}\text { Daily } \\
\text { light sum } \\
\left(\mathrm{E} \mathrm{m}^{-2}\right)\end{array}$ & $\begin{array}{c}\text { Max. } \\
\text { light }(\mu E \\
\left.\mathrm{s}^{-1} \mathrm{~m}^{-2}\right)\end{array}$ & $\begin{array}{l}\text { Temper- } \\
\text { ature } \\
\left({ }^{\circ} \mathrm{C}\right)\end{array}$ & $\mathrm{n}$ & $\begin{array}{c}P_{\max } \\
\left(\mathrm{mg} \mathrm{O}_{2}\right. \\
\left.\mathrm{m}^{-2} \min ^{-1}\right)\end{array}$ & $P / R$ & $\begin{array}{c}l_{c} \\
(\mu E \\
\left.m^{-2} s^{-1}\right)\end{array}$ & $\begin{array}{c}I_{k} \\
(\mu \mathrm{E} \\
\left.\mathrm{m}^{-2} \mathrm{~s}^{-1}\right)\end{array}$ & $\begin{array}{c}\alpha \\
(\mu \mathrm{mol} \\
\left.\mathrm{O}_{2} \mu \mathrm{E}\right)\end{array}$ & $\begin{array}{l}\text { Chloro- } \\
\text { phyll a } \\
\left(\mathrm{mg} \mathrm{m}^{-2}\right)\end{array}$ \\
\hline \multicolumn{11}{|l|}{1996} \\
\hline February & $\begin{array}{l}30.7 \\
(7.1)\end{array}$ & $\begin{array}{l}1318 \\
(238)\end{array}$ & $\begin{array}{l}30.0 \\
(0.3)\end{array}$ & 9 & $\begin{array}{c}6.14^{-1} \\
(0.47)\end{array}$ & $\begin{array}{r}2.85^{\circ} \\
(0.27)\end{array}$ & $\begin{array}{r}92^{a} \\
(11)\end{array}$ & $\begin{array}{r}975^{a} \\
(118)\end{array}$ & $\begin{array}{r}0.0038^{\mathrm{a}, \mathrm{c}} \\
\left(6.6 \times 10^{-4}\right)\end{array}$ & $\begin{array}{l}6.3^{\mathrm{d}, c} \\
(0.7)\end{array}$ \\
\hline March & $\begin{array}{l}27.7 \\
(2.3)\end{array}$ & $\begin{array}{l}1325 \\
(99)\end{array}$ & $\begin{array}{l}27.8 \\
(0.3)\end{array}$ & 15 & $\begin{array}{r}5.65^{\circ} \\
(0.45)\end{array}$ & $\begin{array}{l}3.24^{\mathrm{cil}, \mathrm{r}} \\
(0.17)\end{array}$ & $\begin{array}{l}72^{\mathrm{d} . \mathrm{c}} \\
(6)\end{array}$ & $\begin{array}{l}860^{d, \varepsilon} \\
(73)\end{array}$ & $\begin{array}{c}0.0036^{c} \\
\left(2.3 \times 10^{-4}\right)\end{array}$ & $\begin{array}{r}8.5^{r} \\
(0.4)\end{array}$ \\
\hline May & $\begin{array}{l}19.8 \\
(1.3)\end{array}$ & $\begin{array}{l}999 \\
(19)\end{array}$ & $\begin{array}{l}27.6 \\
(0.1)\end{array}$ & 16 & $\begin{array}{l}6.72^{\mathrm{a}} \\
(0.54)\end{array}$ & $\begin{array}{l}3.27^{\mathrm{a}, \mathrm{c}} \\
(0.26)\end{array}$ & $\begin{array}{l}55^{\mathrm{b}, c} \\
(5)\end{array}$ & $\begin{array}{l}670^{a, b, c} \\
(27)\end{array}$ & $\begin{array}{r}0.0053^{\mathrm{dib}} \\
\left(4.6 \times 10^{-4}\right)\end{array}$ & $\begin{array}{r}8.4^{\mathrm{c}} \\
(0.4)\end{array}$ \\
\hline July & $\begin{array}{l}22.5 \\
(0.2)\end{array}$ & $\begin{array}{l}1002 \\
(10)\end{array}$ & $\begin{array}{l}22.5 \\
(0.2)\end{array}$ & 15 & $\begin{array}{r}2.66^{b} \\
(0.18)\end{array}$ & $\begin{array}{r}2.88^{+1} \\
(0.27)\end{array}$ & $\begin{array}{l}56^{a, b, c} \\
(8)\end{array}$ & $\begin{array}{l}482^{\mathrm{b}, c, \mathrm{~d}} \\
(21)\end{array}$ & $\begin{array}{c}0.0028^{r} \\
\left(1.6 \times 10^{-4}\right)\end{array}$ & $\begin{array}{r}5.8^{\circ} \\
(0.4)\end{array}$ \\
\hline September & $\begin{array}{l}20.3 \\
(1.1)\end{array}$ & $\begin{array}{l}1184 \\
(60)\end{array}$ & $\begin{array}{l}23.1 \\
(0.1)\end{array}$ & 10 & $\begin{array}{r}3.26^{\mathrm{b}} \\
(0.29)\end{array}$ & $\begin{array}{r}2.42^{\mathrm{a}} \\
(0.34)\end{array}$ & $\begin{array}{l}68^{a, b, c} \\
\text { (11) }\end{array}$ & $\begin{array}{l}645^{a, b} \\
(73)\end{array}$ & $\begin{array}{c}0.0028^{c} \\
\left(2.9 \times 10^{-4}\right)\end{array}$ & $\begin{array}{l}6.6^{\mathrm{d,c}} \\
(0.3)\end{array}$ \\
\hline December & $\begin{array}{l}25.0 \\
(4.0)\end{array}$ & $\begin{array}{c}1342 \\
(86)\end{array}$ & $\begin{array}{l}28.1 \\
(0.5)\end{array}$ & 8 & $\begin{array}{r}7.16^{\mathrm{a}} \\
(0.26)\end{array}$ & $\begin{array}{l}4.43^{b, c} \\
(0.33)\end{array}$ & $\begin{array}{l}47^{\mathrm{b}, \mathrm{c}} \\
(5)\end{array}$ & $\begin{array}{l}802^{a, e} \\
(93)\end{array}$ & $\begin{array}{l}0.0049^{a} \cdot b, c \\
\left(4.2 \times 10^{-4}\right)\end{array}$ & $\begin{array}{l}9.1^{a, c} \\
(1.3)\end{array}$ \\
\hline \multicolumn{11}{|l|}{1997} \\
\hline February & $\begin{array}{l}22.5 \\
(4.3)\end{array}$ & $\begin{array}{l}1382 \\
(50)\end{array}$ & $\begin{array}{l}28.7 \\
(0.3)\end{array}$ & 1.1 & $\begin{array}{r}7.02^{\mathrm{a}} \\
(0.41)\end{array}$ & $\begin{array}{l}4.39^{\mathrm{b}, \mathrm{c}} \\
(0.33)\end{array}$ & $\begin{array}{l}37^{1} \\
(2)\end{array}$ & $\begin{array}{l}628^{\text {b.d.e }} \\
(62)\end{array}$ & $\begin{array}{c}0.0065^{b} \\
\left(7.8 \times 10^{-4}\right)\end{array}$ & $\begin{array}{l}13.8^{\mathrm{b}} \\
(1.3)\end{array}$ \\
\hline
\end{tabular}

ation as $461 \mathrm{mg} \mathrm{C} \mathrm{m}^{-2} \mathrm{~d}^{-1}$, equivalent to an annual carbon fixation of approximately $168 \mathrm{~g} \mathrm{~m}^{-2}$

The annual variation of all other parameters measured is shown in Table 2. As expected, both light and temperature showed a maximum in summer and distinctly lower values in July and September. The maximum light intensity in winter was about 200 to $300 \mu \mathrm{E}$ $\mathrm{m}^{-2} \mathrm{~s}^{-1}$ lower than in summer However, the large difference in the daily light sums between February 1996 and February 1997 indicates that light is dependent on several factors such as cloud cover, wave action and turbidity.

The photosynthetic capacity $\left(P_{\max }\right)$ followed the same seasonal pattern as community net and gross production. The ratio of production to respiration $(P / R)$ does not show a seasonal pattern, but was on a high level throughout the study period. The light compensation point $\left(I_{c}\right)$ showed highest values in the first summer studied, however, most values were not significantly different to winter values, and the lowest $I_{\varsigma}$ was measured in the second summer of observation. A similar pattern is observed in the saturation point $\left(I_{k}\right)$. In 1996 the lowest values were observed in winter, but these values were not significantly different from those measured in the following February. The photosynthetic efficiency per unit area $(\alpha)$, which is equivalent to the quantum yield efficiency in the units presented, was generally low compared to the theoretical maximum of 0.1 to 0.125 (Kirk 1983). Although lowest values seem to occur in winter, these were not significantly different from most summer months.
No consistent trend was observed in microalgal biomass (chlorophyll a). Although the lowest values were observed in July 1996, these were not significantly different to values in several summer months.

\section{Effects of light and temperature}

Due to a low level of replication within sampling days we could not test for variation between single observation days. However, examination of the raw data suggested that production related parameters $\left(P_{\max }\right.$ net and gross production) and temperature were relatively stable between days within each month, despite wide variations in daily light conditions, $I_{\mathrm{k}}$ and $I_{c}$. An extreme situation of these changes is illustrated by the P-I curves of 2 days in February 1996 (Fig. 3). On a calm day in summer, the sum of integrated light at our stations was $35.4 \mathrm{E} \mathrm{m}^{-2} \mathrm{~d}^{-1}$ whereas values were reduced to $16.7 \mathrm{E} \mathrm{m}^{-2} \mathrm{~d}^{-1}$ on an overcast day only $2 \mathrm{~d}$ later (Fig 3a). The respective $P$-I curves, averaged over 4 dome chambers, showed a rapid adaptation of the algal community to these changes in light condi-

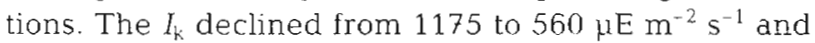
the $I_{\mathrm{c}}$ from 84 to $65 \mu \mathrm{E} \mathrm{m}^{-2} \mathrm{~s}^{-1}$ with decreasing light. Due to adaptation, there is little variation in $P_{\max ,}$ and community net and gross carbon production at most were only slightly reduced on days with less light. To illustrate the adaptation, we calculated the amount of carbon that would be produced by the algal community if the $I_{\mathrm{k}}$ and $I_{\mathrm{c}}$ did not adapt to changes in light 

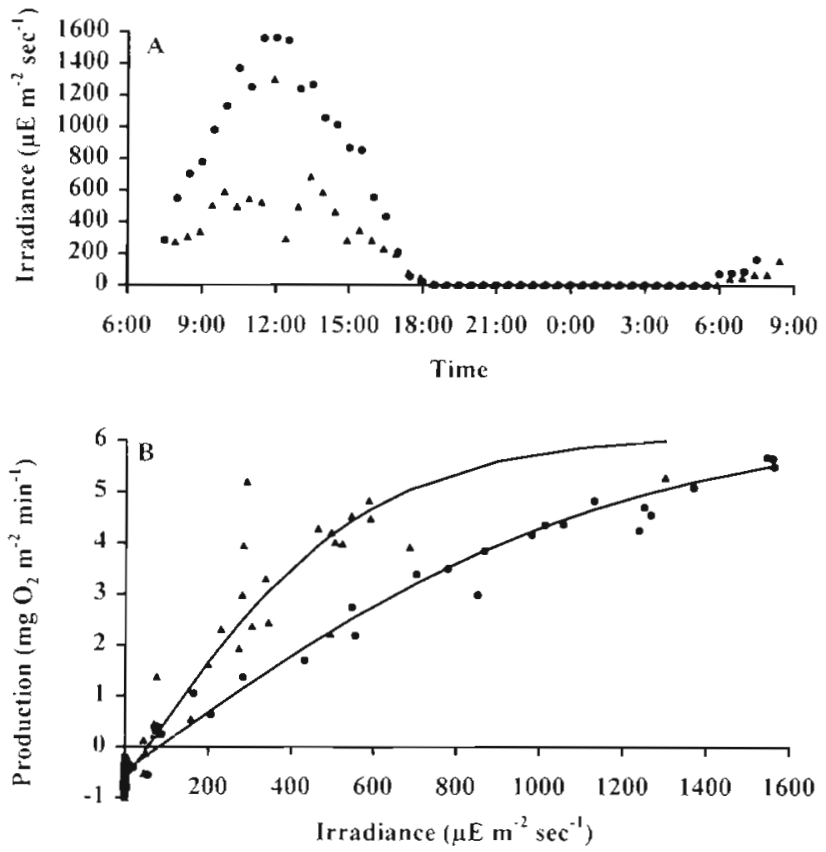

Fig. 3. (A) Thirty minute average light values and (B) corresponding $P-I$ curves average response in 4 dome chambers) for 2 days in February 1996. (•) A sunny day with no cloud cover, (4) an overcast day only 4 d later

conditions. Applying the P-I parameters of the sunny day to the light values of the overcast day yielded a community net production of only $234 \mathrm{mg} \mathrm{C} \mathrm{m}^{-2} \mathrm{~d}^{-1}$, which is $56 \%$ lower than the actual value measured over the overcast day $\left(530 \mathrm{mg} \mathrm{C} \mathrm{m}^{-2} \mathrm{~d}^{-1}\right)$.
Multiple regression analyses indicated that for most variables a large part of the variation between days may be explained either by temperature or light (Table 3). In this model, 63 to $75 \%$ of the variation in community net and gross production, $P_{\max }$ and $\alpha$ were explained by the rather slow and seasonal changes in temperature. Daily irradiance, which changes more rapidly between the single observation days, explained a significant proportion of the variation in $P_{\max }$, $\alpha, I_{c}$ and $I_{k}$. The relationship between light and the latter 2 parameters was positive which corroborates the observations of the rapid adaptation to different light conditions discussed above (Fig. 3). Only a small part of the variations in algal biomass was explained by temperature, and about $80 \%$ of the changes in biomass changes remained unexplained

\section{Effect of nutrients excreted by holothurians}

The injection of holothurian excretion products into dome chambers led to significant differences in $\mathrm{NH}_{4}{ }^{+}$ concentrations between the treatment and the control (Table 4). The $\mathrm{NH}_{4}^{+}$concentration $5 \mathrm{~min}$ after the flushing was significantly higher inside the dome chambers of the 'enhanced' treatment, but the enhancement was only about $0.06 \mathrm{~mol} \mathrm{I}^{-1}$ in December and $0.16 \mu \mathrm{mol} \mathrm{l}^{-1}$ in February (Table 5). The background $\mathrm{NH}_{4}{ }^{+}$values in February 1997 were more than twice as high as in December.

Several of the production related parameters in our experiments showed significant effects due to the

Table 3. Multiple regression analyses with Temperature $\left({ }^{\circ} \mathrm{C}\right)$ and Irradiance $\left(E \mathrm{~m}^{-2} \mathrm{~d}^{-1}\right)$ as independent variables. Dependent

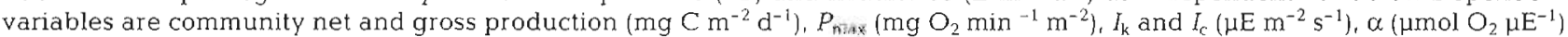
and algal biomass (mg chl a $\mathrm{m}^{-2}$ ). Beta: standardised regression coefficient; Partial $\mathrm{R}^{2}$ the proportion of variance explained by one factor if the other factor is held constant; model. $\mathrm{R}^{2}$ the proportion of the variance explained by the combination of the 2 factors. The model $\mathrm{R}^{2}$ is in all cases highly significant $(p<0.001)$ with the exception of biomass data $(p=0.088)$, no correlation exists between the independent variables light and temperature $\left(R^{2}=0.11, p=0.114\right)$

\begin{tabular}{|c|c|c|c|c|c|}
\hline Dependent variable & Independent variable & Beta & Partial R ${ }^{2}$ & $\mathrm{p}$ & Model $R^{2}$ \\
\hline Net production & $\begin{array}{l}\text { Temperature } \\
\text { Irradiance }\end{array}$ & $\begin{array}{r}0.84 \\
-0.17\end{array}$ & $\begin{array}{l}0.63 \\
0.07\end{array}$ & $\begin{array}{r}<0.001 \\
0.244\end{array}$ & 0.64 \\
\hline Gross production & $\begin{array}{l}\text { Temperature } \\
\text { Irradiance }\end{array}$ & $\begin{array}{r}0.88 \\
-0.20\end{array}$ & $\begin{array}{l}0.70 \\
0.10\end{array}$ & $\begin{array}{r}<0.001 \\
0.139\end{array}$ & 0.70 \\
\hline$P_{\max }$ & $\begin{array}{l}\text { Temperature } \\
\text { Irradiance }\end{array}$ & $\begin{array}{r}0.92 \\
-0.39\end{array}$ & $\begin{array}{l}0.75 \\
0.35\end{array}$ & $\begin{array}{r}<0.001 \\
0.004\end{array}$ & 0.75 \\
\hline$I_{\mathrm{k}}$ & $\begin{array}{l}\text { Temperature } \\
\text { Irradiance }\end{array}$ & $\begin{array}{l}0.32 \\
0.61\end{array}$ & $\begin{array}{l}0.19 \\
0.46\end{array}$ & $\begin{array}{l}0.043 \\
0.001\end{array}$ & 0.61 \\
\hline$I_{\mathrm{C}}$ & $\begin{array}{l}\text { Temperature } \\
\text { Irradiance }\end{array}$ & $\begin{array}{r}-0.13 \\
0.71\end{array}$ & $\begin{array}{l}0.19 \\
0.46\end{array}$ & $\begin{array}{l}0.451 \\
0.001\end{array}$ & 0.46 \\
\hline$\alpha$ & $\begin{array}{l}\text { Temperature } \\
\text { Irradiance }\end{array}$ & $\begin{array}{r}0.74 \\
-0.77\end{array}$ & $\begin{array}{l}0.66 \\
0.68\end{array}$ & $\begin{array}{l}<0.001 \\
<0.001\end{array}$ & 0.75 \\
\hline Biomass & $\begin{array}{l}\text { Temperature } \\
\text { Irradiance }\end{array}$ & $\begin{array}{r}0.46 \\
-0.32\end{array}$ & $\begin{array}{l}0.19 \\
0.09\end{array}$ & $\begin{array}{l}0.039 \\
0.148\end{array}$ & 0.21 \\
\hline
\end{tabular}


Table 4. Two-way analyses of variance (factor Enhanced $=$ nutrient enhanced vs unenhanced treatments, Month $=2$ experimental months) for community net and gross production ( $\mathrm{mg} \mathrm{C} \mathrm{m} \mathrm{C}^{-2} \mathrm{~d}^{-1}$ ), P/R (dimensionless), $P_{\max }\left(\mathrm{mg} \mathrm{O} \mathrm{O}_{2} \mathrm{~min}^{-1}\right.$ $\left.\mathrm{m}^{-2}\right), I_{c}$ and $I_{\mathrm{k}}\left(\mu \mathrm{E} \mathrm{m} \mathrm{m}^{-2} \mathrm{~s}^{-1}\right), \alpha\left(\mu \mathrm{mol} \mathrm{O}_{2} \mu \mathrm{E}^{-1}\right)$, chl a $\left(\mathrm{mg} \mathrm{m}^{-2}\right)$, and $\mathrm{NH}_{4}{ }^{+}$concentrations $\left(\mu \mathrm{mol} \mathrm{l^{-1 }}\right)$. df $=$ degrees of freedom. Transformations: see Table $1_{i} \mathrm{NH}_{4}{ }^{+}$data are log transformed $[\ln (x+1)] . P_{\max }, \mathrm{P} / \mathrm{R}, I_{c}, I_{k}$ and $\alpha$ defined in Table 1 legend

\begin{tabular}{|c|c|c|c|c|}
\hline Parameter & Factor & $\mathrm{df}$ & $F$ & $\mathrm{p}$ \\
\hline \multirow{4}{*}{ Net production } & Enhanced & 1 & 4.84 & 0.035 \\
\hline & Month & 1 & 4.81 & 0.035 \\
\hline & Interaction & 1 & 0.25 & 0.621 \\
\hline & Error & 34 & - & - \\
\hline \multirow[t]{4}{*}{ Gross production } & Enhanced & 1 & 3.73 & 0.062 \\
\hline & Month & 1 & 2.74 & 0.106 \\
\hline & Interaction & 1 & 0.01 & 0.916 \\
\hline & Error & 34 & - & - \\
\hline \multirow[t]{4}{*}{$\mathrm{P} / \mathrm{R}$} & Enhanced & 1 & 2.54 & 0.120 \\
\hline & Month & 1 & 2.50 & 0.123 \\
\hline & Interaction & 1 & 2.25 & 0.143 \\
\hline & Error & 34 & - & - \\
\hline \multirow[t]{4}{*}{$P_{\max }$} & Enhanced & 1 & 4.36 & 0.044 \\
\hline & Month & 1 & 0.38 & 0.542 \\
\hline & Interaction & 1 & 0.04 & 0.836 \\
\hline & Error & 34 & - & - \\
\hline \multirow[t]{4}{*}{$I_{c}$} & Enhanced & 1 & 0.18 & 0.674 \\
\hline & Month & 1 & 1.34 & 0.255 \\
\hline & Interaction & 1 & 2.11 & 0.155 \\
\hline & Error & 34 & - & - \\
\hline \multirow[t]{4}{*}{$I_{k}$} & Enhanced & 1 & 0.04 & 0.843 \\
\hline & Month & 1 & 5.19 & 0.029 \\
\hline & Interaction & 1 & 0.17 & 0.679 \\
\hline & Error & 34 & - & - \\
\hline \multirow[t]{4}{*}{$\alpha$} & Enhanced & 1 & 0.55 & 0.463 \\
\hline & Month & 1 & 3.14 & 0.085 \\
\hline & Interaction & 1 & 0.33 & 0.568 \\
\hline & Error & 34 & - & - \\
\hline \multirow[t]{4}{*}{ Chlorophyll a } & Enhanced & 1 & $<0.01$ & 0.980 \\
\hline & Month & 1 & 14.69 & 0.001 \\
\hline & Interaction & 1 & $<0.01$ & 0.949 \\
\hline & Error & 34 & - & - \\
\hline \multirow[t]{4}{*}{$\mathrm{NH}_{4}{ }^{+}$concentration } & Enhanced & 1 & 6.28 & 0.014 \\
\hline & Month & 1 & 60.02 & $<0.001$ \\
\hline & Interaction & 1 & 0.44 & 0.509 \\
\hline & Error & 73 & - & - \\
\hline
\end{tabular}

Table 5. $\mathrm{NH}_{4}{ }^{+}$concentration in dome chambers during the nutrient enhancement experiments ( \pm SE)

\begin{tabular}{|llc|}
\hline Month & Treatment & $\begin{array}{c}\mathrm{NH}_{4}{ }^{+} \text {concentration } \\
\left(\mu \mathrm{mol} \mathrm{^{-1 } )}\right.\end{array}$ \\
\hline December 1996 & Enhanced & $0.28(0.03)$ \\
& Unenhanced & $0.22(0.04)$ \\
February 1997 & Enhanced & $0.71(0.05)$ \\
& Unenhanced & $0.55(0.08)$ \\
\hline
\end{tabular}

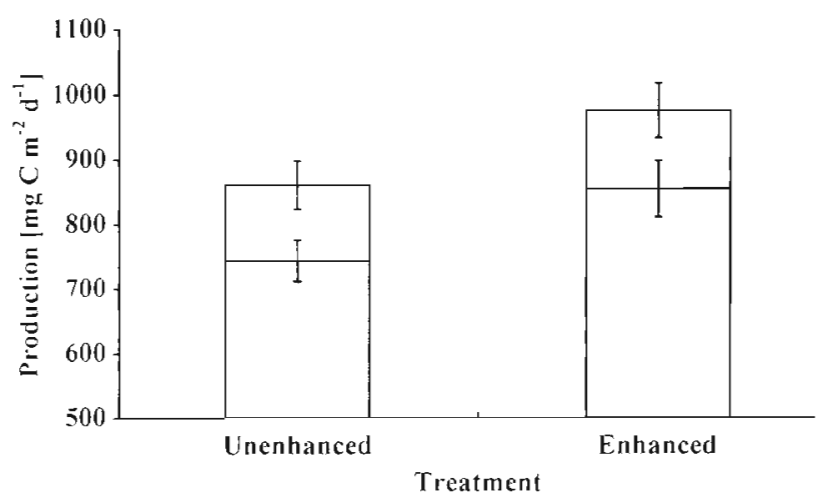

Fig. 4. Average community net production ( \pm SE, hatched bar areas) and community gross production ( \pm SE, total bar area) in the nutrient enhancement experiment. The open bar area represents respiration. Unenhanced: dome chambers flushed with ambient sea water. Enhanced: dome chambers flushed with ambient sea water which passed holothurians

holothurian excretion (Table 4). Both community net and gross production were significantly higher in the enhanced treatments (Fig. 4). Compared to the unenhanced treatments, net production and $P_{\max }$ were enhanced by about $12 \%$ averaged over all experiments. The increase in gross production was only $10 \%$ and only significant at an alpha level of 0.1 , and was thus on the border of the sensitivity of the applied statistical and methodological design.

The net production was significantly higher in December 1996 than in February 1997, in accordance with the results of the seasonal data (see above). Also corresponding with the seasonal measurements, microalgal biomass was significantly higher in February 1997 and the biomass-specific production was higher in December 1996. The $I_{k}$ was significantly higher in December, and $\alpha$ was slightly higher in February presumably due to the decreased light conditions in February.

\section{DISCUSSION}

\section{Magnitude and variation in microphytobenthos community production}

All parameters which express the production of the microalgal community (community net and gross production, $P_{\max }$ ) showed a distinct decline of between 50 and $60 \%$ during the 2 winter months July and September 1996 compared to all months in summer 1996 and 1997. During the whole study period the community was strongly autotrophic with $\mathrm{P} / \mathrm{R}$ ratios between 2.8 and 4.4. The monthly averages for net carbon fixation in summer vary between 573 and $790 \mathrm{mg} \mathrm{C} \mathrm{m}^{-2} \mathrm{~d}^{-1}$ but these were not significantly different from each other 
Net carbon fixation in winter can be as low as $245 \mathrm{mg}$ $\mathrm{C} \mathrm{m}{ }^{2} \mathrm{~d}^{-1}$ Averaging data over the whole year, we suggested an average community carbon fixation of $461 \mathrm{mg} \mathrm{C} \mathrm{m}^{-2} \mathrm{~d}^{-1}$, or an annual carbon fixation of approximately $168 \mathrm{~g} \mathrm{C} \mathrm{m}^{-2}$ for sediments on the reef of Great Palm Island.

Compared to temperate and subtropical shallow water ecosystems, the data from our study are at the upper end of a scale ranging from $32 \mathrm{~g} \mathrm{C} \mathrm{m}^{-2} \mathrm{yr}^{-1}$ (Nienhuis \& De Bree 1984) to $234 \mathrm{~g} \mathrm{C} \mathrm{m}^{-2} \mathrm{yr}^{-1}$ (Pinckney \& Zingmark 1993a). Further references on productivity in temperate regions are listed in Colijn \& de Jonge (1984). In the tropical area, Sournia (1976) calculated the net community production on shallow sediments of Takapoto Atoll between 430 and $1330 \mathrm{~g} \mathrm{C}$ $\mathrm{m}^{-2} \mathrm{yr}^{-1}$. Values on another atoll (Taumotu) ranged from 32 to $702 \mathrm{mg} \mathrm{C} \mathrm{m}^{-2} \mathrm{~d}^{-1}$ (Charpy-Roubaud 1988) and a net photosynthesis of $300 \mathrm{~g} \mathrm{C} \mathrm{m}^{-2} \mathrm{yr}^{-1}$ was measured on Majuro Atoll (Sorokin 1978). Annual net community production on Ningaloo Reef, Western Australia (Masini 1990), was similar to our data (208 g C $\mathrm{m}^{-2} \mathrm{a}^{-1}$ ). On shallow sediments of Davies Reef (central $\mathrm{GBR}$ ), community net production may be negative (P/R $<1$ ), but on deeper sediment ( 16 to $26 \mathrm{~m}$ ) positive production values between 40 and $180 \mathrm{mg} \mathrm{C} \mathrm{m}^{-2} \mathrm{~d}^{-1}$ were found (Hansen et al. 1987). Johnstone et al. (1990) also found distinctly lower values of community net production in winter compared to the summer on One Tree Island (southern GBR). The magnitude of community net production in the latter study was much lower (-3 to $50 \mathrm{mg} \mathrm{C} \mathrm{m}^{-2} \mathrm{~d}^{-1}$ ) compared to our study and the $\mathrm{P} / \mathrm{R}$ ratios were much closer to unity than the data from Great Palm Island.

To calculate the actual net photosynthesis (or primary production), Johnstone et al. (1990) assumed that respiration of the algal community alone equals $10 \%$ of the gross production and obtained net primary production values between 570 and $1710 \mathrm{mg} \mathrm{C} \mathrm{m}^{-2} \mathrm{~d}^{-1}$. If we follow this approach, we arrive at an average net primary production of $944 \mathrm{mg} \mathrm{C} \mathrm{m}^{-2} \mathrm{~d}^{-1}$ in summer and $487 \mathrm{mg} \mathrm{C}$ $\mathrm{m}^{-2} \mathrm{~d}^{-1}$ in winter, or an estimated primary production of $261 \mathrm{~g} \mathrm{C} \mathrm{m}^{-2} \mathrm{yr}^{-1}$. The assumption that respiration is only $10 \%$ is debatable ${ }_{i}$ however, conversion of our data by this approach indicated that the main difference between our data from Great Palm Island and the data from One Tree Island (Johnstone et al. 1990) was not the amount of primary production but the amount of production directly assimilated by bacteria and infauna. It appears that assimilation by consumers is higher at One Tree Island. Net algal production on sediments of lizard Island (northern GBR) ranged from $66 \mathrm{mg} \mathrm{C} \mathrm{m}^{-2} \mathrm{~d}^{-1}$ in winter to $350 \mathrm{mg} \mathrm{C} \mathrm{m}^{-2} \mathrm{~d}^{-1}$ in summer (Moriarty et al. 1985). These authors used the common approach of obtaining daily production rates by projecting short term ${ }^{14} \mathrm{C}$ fixation measurements
Thus, our data on community net production for a near-shore reef in the GBR are considerably higher than those for a midshelf reef (Hansen et al. 1987) and 2 offshore island reefs (Moriarty et al. 1985, Johnstone et al. 1990) of the GBR. However, more data on spatial distribution of benthic community production are needed to evaluate whether higher net production on near-shore reefs represents a general pattern.

\section{P-I curve parameters}

The sediment community as a whole responded to varying light intensities in a fashion similar to higher organised aquatic plants (examples in Kirk 1983) in that the relation between light and photosynthesis could be described by typical $P-I$ curves. The light compensation point $\left(I_{c}\right)$ was on a relatively high level compared to other tropical marine primary producers such as turf algae (Klumpp \& McKinnon 1989). The low $I_{c}$ found in our study may not be surprising since the community net production we measured includes a large proportion of respiration by bacteria and infauna (see above). Monthly averages of the light saturation point $\left(I_{k}\right)$ were as high as $975 \mu \mathrm{E} \mathrm{m}^{-2} \mathrm{~s}^{-1}$. These values are high compared with data of other coral reef primary producers; a range of 200 to $400 \mu \mathrm{E} \mathrm{m} \mathrm{m}^{-2} \mathrm{~s}^{-1}$ is reported for turf algae (Klumpp \& McKinnon 1989), folious macroalgae (Klumpp et al. in press) or corals (Chalker 1981). In temperate regions, $I_{\mathrm{k}}$ values of sediment communities ranged from $170 \mu \mathrm{E} \mathrm{m}^{-2} \mathrm{~s}^{-1}$ (Mills \& Wilkinson 1986) to $800 \mu \mathrm{E} \mathrm{m}^{-2} \mathrm{~s}^{-1}$ (Pinckney \& Zing-

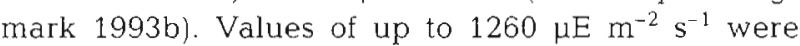
found on subtropical sediments (Shaffer \& Onuf 1985), but Masini (1990) recorded much lower $I_{k}$ values $(95$ to $130 \mu \mathrm{E} \mathrm{m}^{-2} \mathrm{~s}^{-1}$ ) in coral reef sediments of Ningaloo Reef, Western Australia. The latter data were obtained for core samples under artificial conditions in the laboratory. In a previous laboratory study, Uthicke \& Klumpp (1997) measured distinctly lower $I_{k}$ (and also $\left.I_{c}\right)$ values in Great Palm Island sediments, cultivated in petri dishes. Preliminary trials with sediments in plastic dishes measured in situ also yielded lower $I_{k}$ and $I_{c}$ (Uthicke \& Klumpp unpubl. data). The decreased $I_{k}$ and $I_{\mathrm{C}}$ indicate that measurements of the photosynthetic saturation and compensation points for microbenthic algae are susceptible to disturbance of the sample or to alterations of the sediment depth. The method we applied measured depth integrated production and respiration, which means the biomass of microalgae involved in production increases with increasing irradiance due to a deeper penetration of light into the sediment (Pinckney \& Zingmark 1993b). Thus, at higher light intensities a larger biomass is 
involved which leads to a delayed saturation of production and consequently a higher $I_{\mathrm{k}}$.

We presented area-specific values for the photosynthetic efficiency $(\alpha)$ since these directly express the quantum yield efficiency (Droop et al. 1982, Mills \& Wilkinson 1986) if suitable units are chosen, i.e. moles of carbon fixed per moles of quanta. In optimum conditions, this value may reach a maximum of 0.1 to 0.125 and values less than 0.1 indicate nutrient limitation (Kirk 1983). We found an average value of 0.0042 , which is approximately 5 times less than quantum efficiencies measured in microbenthos communities in Scotland (Mills \& Wilkinson 1986) which were regarded as nutrient limited. A similarly low quantum efficiency was measured in turf algae of the GBR (Klumpp \& McKinnon 1989) and the Carribean (Carpenter 1985). Converting our $\alpha$-values to biomassspecific efficiencies gives an average of $0.06 \mu \mathrm{g} \mathrm{O} \mathrm{O}_{2}$ ( $\mu \mathrm{g}$ chl $a)^{-1} \mathrm{~h}^{-1}\left(\mu \mathrm{E} \mathrm{m}^{-2} \mathrm{~s}^{1}\right)^{-1}$ which is nearly twice as high as Mill's \& Wilkinson's (1986) $\alpha$-values. Since these authors calculated a higher quantum efficiency per unit area, their sediments must have been much richer in algal biomass. The biomass-specific photosynthetic efficiencies on sediments of Great Palm Island are in the same range as those of benthic microalgae in Texas $\left(27^{\circ} \mathrm{N}\right.$; Blanchard \& Montagna 1992) and 3 and 5 times higher than those found on the east

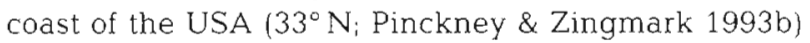
and Western Australia $\left(22^{\circ} \mathrm{S}\right.$; Masini 1990), respectively. However, as mentioned earlier, it is difficult to determine the biomass involved in the productivity of sediment communities at any given light level and thus the calculation of a biomass-specific $\alpha$-value may be erroneous. Furthermore, care should be taken in comparing microalgal biomass estimates since a variety of different extraction methods are used by different authors.

\section{Effects of light and temperature}

Microalgal biomass and $P$ - $I$ curve parameters, apart from $P_{\max }$ did not exhibit the clear, seasonal trend which was evident in overall community production (see above). Multiple regression analyses revealed that changes in temperature, which has a strong seasonal component, explained 63 to $75 \%$ of the variation in $P_{\max }$ community net and gross production. Temperature also had a strong influence on the quantum yield efficiency. In temperate benthic microalgae, a temperature increase of $1^{\circ} \mathrm{C}$ may lead to a $10 \%$ increase of photosynthesis (Colijn \& van Burt 1975). The increase in $P_{\max }$ of sediment microalgae with temperature has also been observed for temperate intertidal microalgal communities (Mills \& Wilkinson 1986). It seems likely that temperature effects outside the light-limited part of the $P$-I curve (e.g. on $P_{\max }$ ) reflect a decreased enzyme activity in the dark carboxylation system at lower water temperatures (Kirk 1983).

Although a tendency for lower irradiance in winter seems intuitive, irradiance measured in some summer months was as low as winter values due to weather and turbidity conditions. Ecologically the most interesting aspects may be the rapid adaptation of the algal community, indicated by $I_{k}$ and $I_{c}$, to the daily light conditions, and that irradiance explained $46 \%$ of the variance in these $P-I$ parameters. Rapid adaptability enables the algal community to minimise variation in production despite drastic variations in light conditions. Similarly, light-adapted microalgal communities on open mudflats may have a much higher $I_{\mathrm{k}}$ than shade-adapted communities under a macrophyte canopy (Pinckney \& Zingmark 1993b). On the sediments of Great Palm Island, irradiance was negatively correlated to quantum yield efficiency and $P_{\max }$. Blanchard \& Montagna (1992) observed a correlation between these 2 parameters in temperate microalgal communities and explained this by response to light as a common factor. The increase in the initial slope of the $P-I$ curve or quantum efficiency $(\alpha)$ with decreasing light was also observed in tropical turf algae (Carpenter 1985) and may represent an additional adaptation to lower light. Photo-acclimatisation may be explained by a change of size or number of photosynthetic units in the microalgae (Pinckney \& Zingmark 1993b) or, as discussed earlier, in a different biomass involved in production under varying light conditions. Furthermore, we cannot exclude the possibility that different species of microalgae may be involved in different light conditions or that more microalgae migrate to the sediment surface in higher light conditions.

\section{Effect of nutrients excreted by holothurians}

Averaged over the 2 experimental months the $\mathrm{NH}_{4}{ }^{+}$ levels in dome chambers receiving water containing holothurian excretion were about $0.1 \mu \mathrm{mol} \mathrm{l^{-1 }}$ above the corresponding level in control chambers. Despite a very small increase in $\mathrm{NH}_{4}{ }^{+}$concentrations, there was a significantly higher community net and gross production (10 to $12 \%$ ) in the enhanced treatment, compared with unenhanced controls

Uthicke \& Klumpp (1997) used a similar enhancement technique in aquarium experiments and did not detect increases in phosphate, nitrite or nitrate, although $\mathrm{NH}_{4}{ }^{+}$enhancement was much higher than in the present study, excretion of dissolved organic phosphorus or organic nitrogen was not detectable in Holothuria atra (Uthicke unpubl. data). Thus we 
assume that the production enhancement in the present study was mainly due to the enhanced $\mathrm{NH}_{4}{ }^{+}$levels in the treatments. However, a small amount of phosphate is also released by $H$. atra (Uthicke unpubl. data) and thus a contributing effect of phosphate cannot be excluded. In aquaria experiments, an enhancement of $0.6 \mu \mathrm{mol} \mathrm{NH}_{4}^{+} \mathrm{l}^{-1}$ led to a $34 \%$ increase in community net and gross production and $23 \%$ in photosynthetic efficiency $(\alpha)$. Accompanying the production increase, an accumulation of phaeopigments indicated an enhanced turnover of biomass (Uthicke \& Klumpp 1997). The increase of $\alpha$ in nitrogen-enriched treatments of the latter study may support the concept that a low photon yield efficiency is an indicator for nutrient limitation (Droop et al. 1982, Mills \& Wilkinson 1986). The low $\alpha$-values encountered throughout our study, in conjunction with the result of the enhancement experiment, indicate that microphytobenthos productivity on Great Palm Island is limited by the availability of inorganic nitrogen. Since nutrient $\left(\mathrm{NH}_{4}{ }^{+}\right.$and $\left.\mathrm{PO}_{4}{ }^{2-}\right)$ concentrations in the interstitial water at our sampling stations is at least an order of magnitude higher than in the water column (Uthicke unpubl. data) further research is required to understand why benthic microalgae react to relatively small additions of nutrients.

The much higher $\mathrm{NH}_{4}{ }^{+}$baseline data in February 1997 did not lead to an enhanced production in that month compared to December. In contrast, biomass in February 1997 was significantly higher than in December. An increase in $\mathrm{NH}_{4}{ }^{+}$concentration between December and February may have initially led to enhanced production which resulted in the accumulation of biomass during that period. The resulting larger biomass might now be in a new equilibrium with the $\mathrm{NH}_{4}{ }^{+}$level with a higher nutrient demand per unit area. Biomass-specific production may be reduced by some degree of self-shading of the algae, and thus the areal productivity in February 1997 is not higher than in December.

Although field observations from Hawaii indicated that enhanced nutrient levels on coral reefs lead to a community shift towards algae and subsequent degradation of the reef (Smith et al. 1981), only very few experimental field studies are published on the effects of nutrient enhancements on coral reefs (Kinsey \& Davies 1979, Hatcher \& Larkum 1983). In laboratory and field studies, Schaffelke \& Klumpp (1998) showed that large brown algae from Great Palm Island and other near-shore reefs of the GBR are nutrient limited. As in the present study, very low levels of nutrient enhancement resulted in a distinct growth increase, whereas high level enhancement had no effect. Thus, experimental evidence suggests that even a relatively small increase in the level of inorganic nitrogen on the reefs of Great Palm Island, and probably other near- shore reefs, will result in a measurable increase in the productivity and biomass of primary producers.

Community net production was a significant source of organic carbon on sediments at our study area and production showed a distinct seasonal pattern. Microphytobenthos will, together with turf algae and abundant folious macroalgae (net production up to $3 \mathrm{~g} \mathrm{C}$ $\mathrm{m}^{-2} \mathrm{~d}^{-1}$; Schaffelke \& Klumpp 1997b), contribute to a high community excess production in the lagoonal area of Great Palm Island. Although temperature and irradiance, in conjunction with grazing by sediment feeder such as holothurians (Moriarty et al. 1985, Uthicke 1998), may modify the productivity of benthic microalgae at Great Palm Island, we suggest that the availability of inorganic nutrients controls microalgal production and biomass.

Acknowledgements. We express our gratitude to the masters and crews of the RV 'Harry Messel' and RV 'Lady Basten' Many volunteers assisted during the field work and we are especially grateful for the help of Michael Tyler. The manuscript greatly benefited from the comments of 3 anonymous reviewers. This study is based on a doctoral study by S.U. at the Faculty of Biology, University of Hamburg. This is AIMS publication No. 920 .

\section{LITERATURE CITED}

Baillie PW (1986) Oxygenation of intertidal estuarine sediments by benthic microalgal photosynthesis. Estuar Coast Shelf Sci 22:143-159

Blanchard G, Montagna PA (1992) Photosynthetic response of natural assemblages of marine benthic microalgae to short- and long-term variations of incident irradiance in Baffin Bay, Texas. J Phycol 28:7-14

Carpenter RC (1985) Relationship between primary production and irradiance in coral reef communities. Limnol Oceanogr 30:785-793

Chalker BE (1981) Simulating light-saturation curves for photosynthesis and calcification by reef building corals. Mar Biol 63:135-141.

Charpy-Roubaud CJ (1988) Production primaire des fonds meubles du lagon de Tikehau (Atoll des Tuamotu, Polynesie française). Oceanol Acta 11:241-248

Colijn F, de Jonge VN (1984) Primary production of microphytobenthos in the Ems-Dollard Estuary. Mar Ecol Prog Ser 14:185-196

Colijn. F, van Burt G (1975) Influence of light and temperature on photosynthetic rate of marine benthic diatoms. Mar Biol 31:209-214

Droop MR, Mickelson MJ, Scott JM, Turner MF (1982) Light and nutrient status of algal cells. J Mar Biol Assoc UK 62: $403-434$

Furnas M. Mitchel AW, Skuza M (1995) Nitrogen and phosphorus budgets for the Central Great Barrier Reef shelf. Great Barrier Reef Marine Park Authority, Research Publication No. 36, Townsville

Hatcher BG, Larkum AWD (1983) An experimental analyses of factors controlling the standing crop of the epilithic algal community on a coral reef. J Exp Mar Biol Ecol 69: $61-84$

Hansen JA, Alongi DM, Moriarty DJW, Pollard PC (1987) The 
dynamics of benthic microbial communities at Davies Reef, Central Great Barrier Reef. Coral Reefs 6:63-70

Johnstone RW, Koop K, Larkum AWD (1990) Physical aspects of coral reef lagoon sediments in relation to detritus processing and primary production. Mar Ecol Prog Ser 66: 273-283

Kinsey DW, Davies P (1979) Effects on elevated nitrogen and phosphorus on coral reef growth. Limnol Oceanogr 24: 935-940

Kirk JTO (1983) Light and photosynthesis in aquatic ecosystems. Cambridge University Press, London

Klumpp DW, Done TJ, McKinnon AD, Robertson AI, Brunskill GJ (in press) Response of near-shore reefs to nutrient enhancement Phase I: Baseline information on nutrient concentrations, primary production and reef community structure. Research Publication, Great Barrier Reef Marine Park Authority, Townsville

Klumpp DW. McKinnon AD (1989) Temporal and spacial patterns in primary production of a coral-reef epilithic algal community. J Exp Mar Biol Ecol 131:1-22

Klumpp DW, McKínnon D, Daniel P (1987) Damselfish territories: zones of high productivity on coral reefs. Mar Ecol Prog Ser 40:40-51

Koroleff F (1983) Determination of ammonia. In: Grasshoff K, Ehrhard M. Kremling K (eds) Methods of seawater analysis. Verlag Chemie, Weinheim, p 150-157

Masini RJ (1990) The ecological significance of benthic microalgae in Western Australian aquatic ecosystems. PhD thesis, Department of Botany, University of Western Australia, Nedlands

Mills DK, Wilkinson M (1986) Photosynthesis and light in estuarine benthic microalgae. Botanica Mar 14:125-129

Moriarty DJW, Pollard PC, Hunt WG, Moriarty CM, Wassenberg TJ (1985) Productivity of bacteria and microalgae and the effect of grazing by holothurians in sediments on a coral reef flat. Mar Biol 85:293-300

Nienhuis PH, De Bree BHH (1984) Carbon fixation and chlorophyll in bottom sediments of brackish Lake Gravelingen, The Netherlands. Neth J Sea Res 18:337-359

Nusch EA (1980) Comparison of different methods for chlorophyll and phaeopigment determination. Arch Hydrobiol Beih Ergeb Limnol 14:14-30

Pinckney J, Zingmark RG (1993a) Biomass and production of benthic microalgal communities in estuarine habitats. Estuaries 16:887-897

Pinckney J, Zingmark RG (1993b) Photophysiological responses of intertidal benthic microalgal communities to in situ light environments: methodological considerations. Limnol Oceanogr 38:1373-1383

Editorial responsibility: Daniel Alongi (Contributing Editor), Townsville, Queensland, Australia
Sartory DP, Grobbelaar JU (1984) Extraction of chlorophyll a from freshwater phytoplankton for spectrophotometric analysis. Hydrobiologia 114:177-187

Schaffelke B, Klumpp DW (1997a) Biomass and productivity of tropical macroalgae on three near shore fringing reefs in the Central Great Barrier Reef, Australia. Botanica Mar 40:373-383

Schaffelke B, Klumpp DW (1997b) Growth of germlings of the macroalga Sargassum baccularia (Phaeophyta) is stimulated by enhanced nutrients. Proc 8 th Int Coral Reef Symp 2:1839-1842

Schaffelke B, Klumpp DW (1998) Nutrient-limited growth of the coral reef macroalga Sargassum baccularia and experimental growth enhancement by nutrient addition in continuous flow culture. Mar Ecol Prog Ser 164:199-211

Shaffer GP, Onuf CP (1985) Reducing the error in estimating annual production of benthic microflora: hourly to monthly rates, patchiness in space and time. Mar Ecol Prog Ser 26:221-231

Smith SV, Kimmer WJ, Laws EA, Brock RE, Walsh TW (1981) Kaneohe Bay sewage diversion experiment: perspectives on ecosystem responses to nutritional dispersion. Pac Sci $35: 279-395$

Sorokin YI (1978) Microbial production in the coral-reef community. Arch Hydrobiol 83:281-323

Sorokin YI (1990) Aspects of trophic relations, productivity and energy balance in coral-reef ecosystems. In: Dubinsky $Z$ (ed) Ecosystems of the world: 25. Coral reefs. Elsevier, Amsterdam, p 401-410

Sorokin YI (1993) Coral reef ecology. Ecological Studies, Vol 192. Springer-Verlag, Berlin

Sournia A (1976) Primary production of sands in the lagoon of an Atoll and the role of foraminiferan symbionts. Mar Biol $37: 29-32$

Sundbäk K, Granéli W (1988) Influence of microphytobenthos on the nutrient flux between sediment and waters: a laboratory study. Mar Ecol Prog Ser 43:63-69

Uthicke S (1998) Sediment bioturbation and impact of feeding activity of Holothuria (Halodeima) atra and Stichopus chloronotus, two sediment feeding holothurians, at Lizard Island, Great Barrier Reef. Bull Mar Sci 62(2): in press

Uthicke S, Klumpp DW (1997) Ammonium excretion by holothurians enhances production and turnover in benthic diatom communities. Proc 8th Int Coral Reef Symp, Panama, 1996, Smithonian Tropical Research Institute, Balboa, p 873-876

Yingst JY (1976) The utilization of organic matter in shallow marine sediments by an epibenthic deposit feeding holothurian. J Exp Mar Biol Ecol 23:55-69

Submitted: December 2, 1997; Accepted: April 17, 1998

Proofs received from author(s): July 6, 1998 